\title{
Hydrology of the Nevin Wetland near Madison, Wisconsin
}

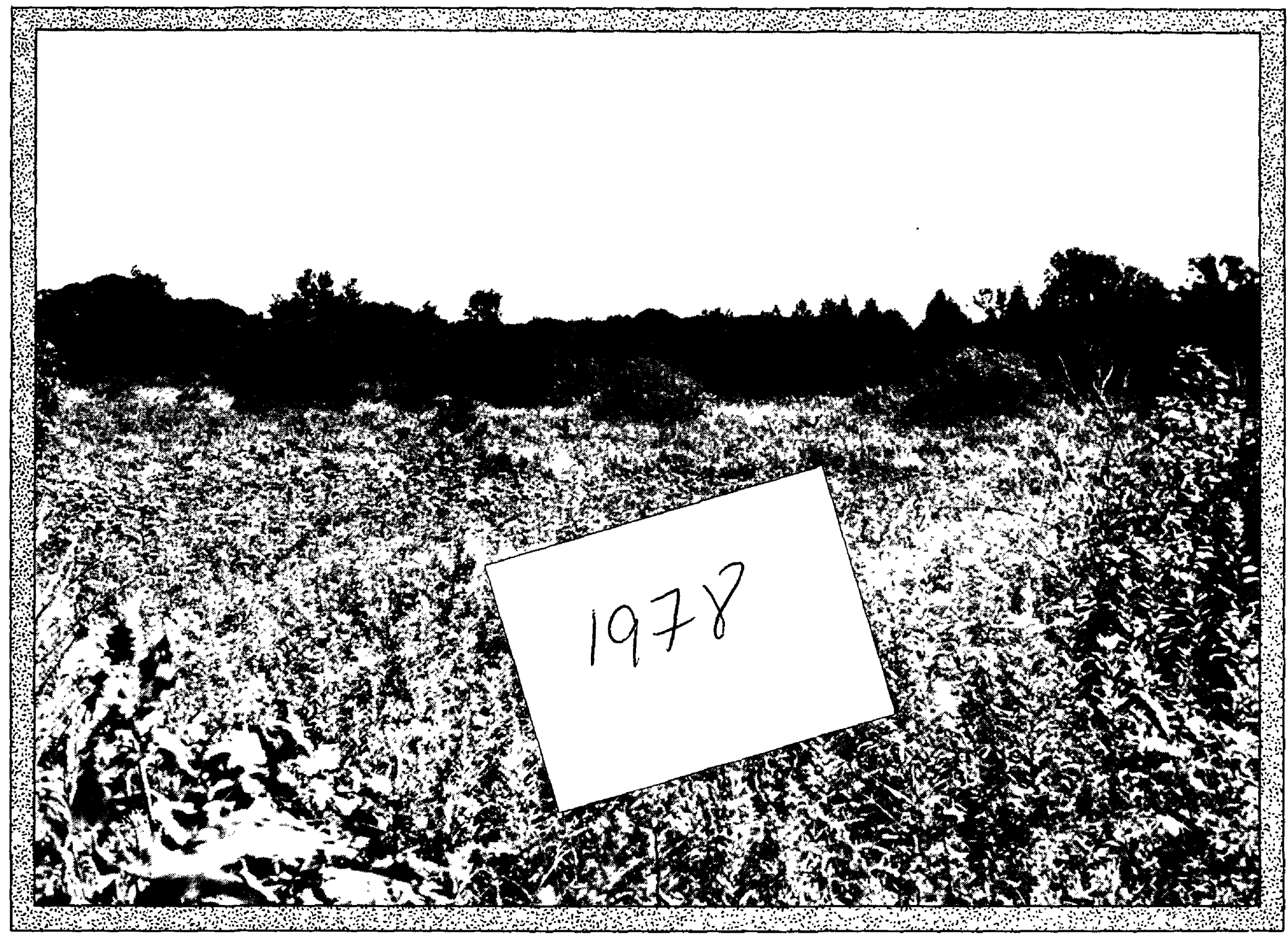

PREPARED BY

\section{UNITED STATES DEPARTMENT OF THE INTERIOR GEOLOGICAL SURVEY}

IN COOPERATION WITH 


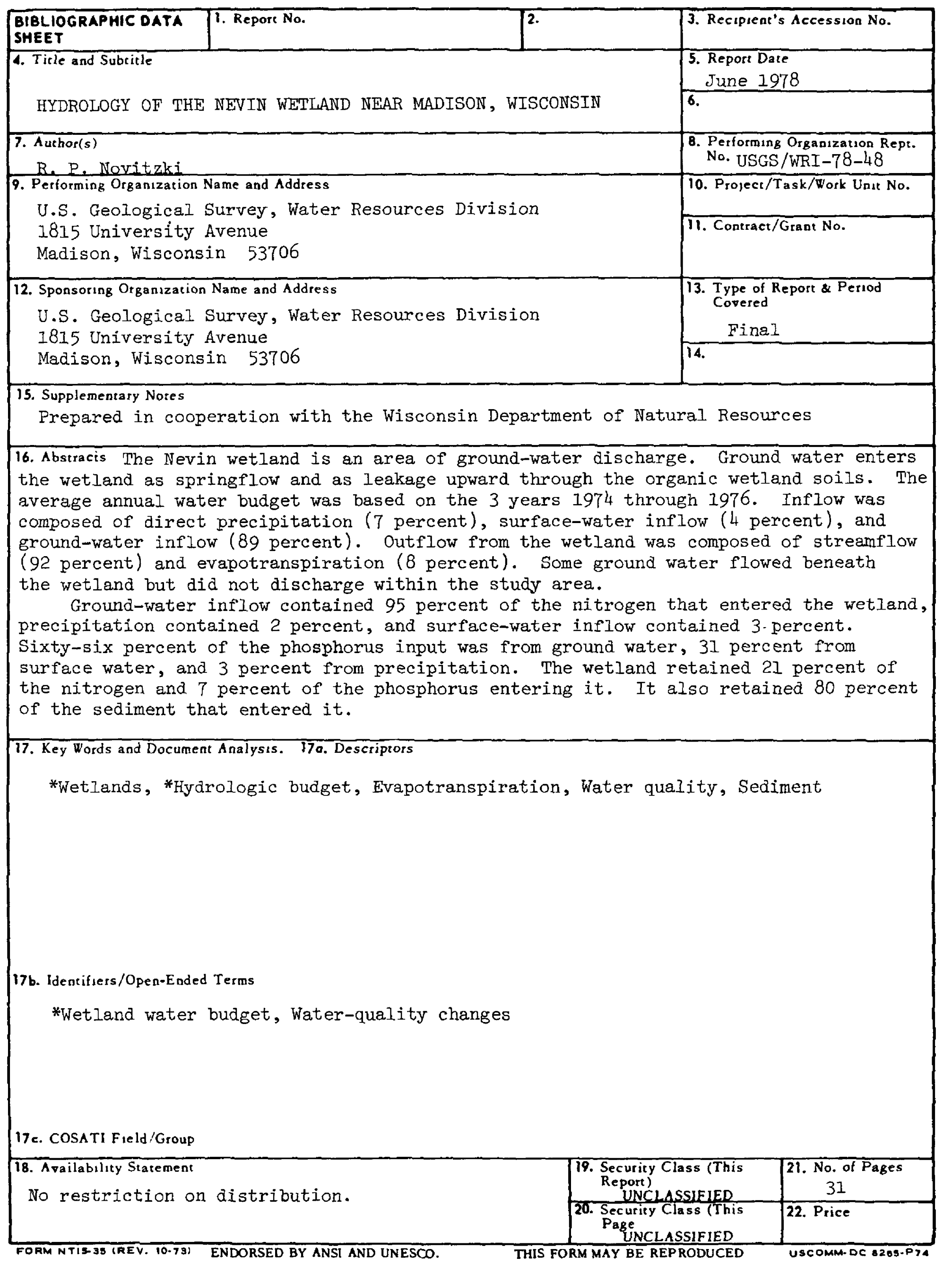




\title{
Hydrology of the Nevin Wetland near Madison, Wisconsin
}

\author{
R. P. Novitzki
}

U.S. GEOLOGICAL SURVEY

Water Resources Investigation 78-48

Prepared in cooperation with the

Wisconsin Department of Natural Resources

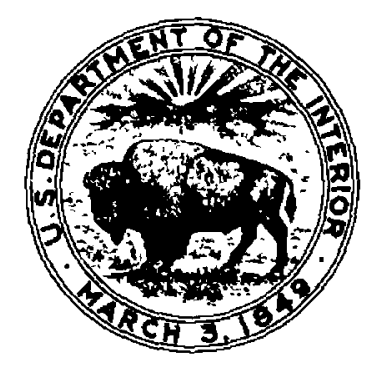

JUNE 1978 


\title{
UNITED STATES DEPARTMENT OF THE INTERIOR
}

\author{
CECIL D. ANDRUS, SECRETARY
}

\section{GEOLOGICAL SURVEY}

H. William Menard, Director

For additional information write to:

U.S. Geological Survey 1815 University Avenue

Madison, Wisconsin 53706 


\section{CONTENTS}

Page

Conversion factors-_-

Abstract-_-_-_- 1

Introduction--_-_-_-_- 2

Purpose-_-_-_-_-_-_- 2

Scope-_-_- 3

Acknowledgments and cooperation-_- 3

Physical setting--_-n 3

Wetland characteristics-_-_- 5

Hydrogeology--..-- 5

Hydrology-_- 8

Water budget-_-_- 8

Inflow-_. 8

Precipitation-- 8

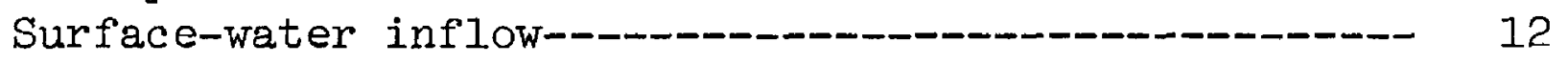

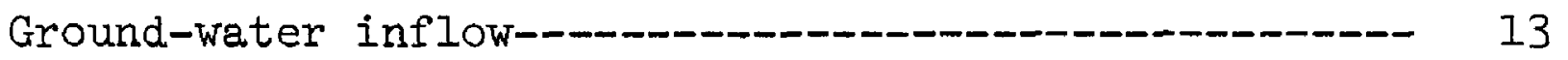

Springs-- 13

Upward leakage--_-_-- 13

Outflow-

Streamflow-_-_-_-_-_- 13

Evapotranspiration-_- 15

Change in storage-- 15

Underflow-_-_- 15

Water quality-_-_-_-_-_- 16

Precipitation-_-_-_-_- 16

Surface-water inflow-_-_-_._-_._- 16

Springflow and leakage-_____n 16

Hatchery discharge-_-_-_-_-_-_-_-_- 17

Surface-water outflow-_-_-_-_- 17

Effect of wetland on water quality-_-_- 17

Factors affecting the wetland-_- 21

Hatchery--_-_- 21

Surface-water inflow from agricultural and undeveloped areas--- 21

Surface-water inflow from developed areas--_-_-_-_-_-_-_-_---- 22

Land-use changes--_-_-_-_- 22

Drainage-_-__- 22

Ground-water pumpage--_-_-_-_- 23

Urbanization-_- 23

Summary--------- 23

Selected references-_-_- 25 


\section{ILLUSTRATIONS}

Page

Figure 1-6. Maps showing:

1. Nevin wetland and location of monitoring sites--- 4

2. Thickness of organic soils_-_-_-_- 6

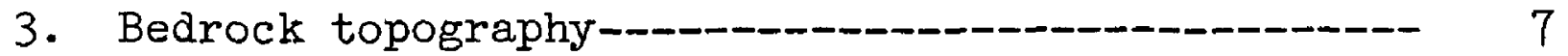

4. Water table-_-_-_- 9

5. Thickness of saturated glacial deposits and generalized geohydrologic section----_----- 10

6. Diagrammatic sketch of the Nevin wetland's water budget elements related to basin geology-_-_- 12

7. Map showing areas of inferred ground-water discharge--- 14

\section{TABLES}

Page

Table 1. Water budget for the Nevin wetland-_- 11

2. Chemical characteristics of water from different sources in the Nevin wetland-_._. 18

3. Nitrogen, phosphorus, and sediment budgets for the Nevin wetland-_- 20 


\section{CONVERSION FACTORS}

All water volumes discussed in this report have been converted to equivalent inches of water on the 120-acre wetland. The following conversion factors are provided for obtaining other familiar units of measure.

Water volume

One inch of water per year

on the 120-acre wetland
Multiplied by

$2.069 \times 10^{-1}$

$1.00 \times 10$

$1.381 \times 10^{2}$

6.120
Yields U.S. customary unit

inches of water per year on the 580-acre wetland. basin

acre-foot per year

cubic feet per second $(\mathrm{ft} 3 / \mathrm{s})$

gallons per minute (gal/min) factors:

To convert U.S. customary units to SI units, use the following conversion

Multiply U.S. customary unit

in (inches)

ft (feet)

gal/min (gallons per minute)

Ib (pounds)

acres

$\mathrm{mi}^{2}$ (square miles)

$\mathrm{ft}^{2}$ (square feet)

$\mathrm{ft}^{3}$ (cubic feet)
By

$2.540 \times 10^{1}$

$3.048 \times 10^{-1}$

$6.309 \times 10^{-2}$

$4.536 \times 10^{-1}$

$4.047 \times 10^{-3}$

2.590

$9.290 \times 10^{-2}$

$2.832 \times 10^{-2}$
To obtain SI unit

$\mathrm{mm}$ (millimeters)

$\mathrm{m}$ (meters)

$\mathrm{L} / \mathrm{s}$ (liters per second) $\mathrm{kg}$ (kilograms) $\mathrm{km}^{2}$ (square kilometers) $\mathrm{km}^{2}$ (square kilometers) $\mathrm{m}^{2}$ (square meters) $\mathrm{m}^{3}$ (cubic meters) 


\title{
Hydrology of the Nevin Wetland near Madison, Wisconsin
}

\author{
R. P. Novitzki
}

\section{ABSTRACT}

The 120-acre Nevin wetland at the south edge of Madison, Wis., is a discharge area of the local ground-water system. A hydrologic unit composed of drift and the upper part of an underlying sandstone sequence provides ground-water inflow. Ground water enters as springflow and as leakage upward through the organic wetland soils.

The average annual water budget for the wetland was based on the 3 years 1974 through 1976. Although 1974 and 1975 were years of more than average precipitation, and 1976 was a year of less than average precipitation, the 3-year average precipitation was only slightly less than the long-term average. Inflow was composed of direct precipitation ( 7 percent), surfacewater inflow from the adjacent uplands ( 4 percent), and ground-water inflow ( 89 percent). Ground-water inflow included springflow, upward leakage, and flow from artesian wells used in the Nevin State Fish Hatchery and discharged as effluent. Outflow was composed of streamflow ( 92 percent) and evapotranspiration ( 8 percent). The amount of water stored in the organic soils varied by only 1 inch during the study. Some ground water flowed beneath the wetland but did not discharge within the study area.

Nutrients were contained in ground-water inflow, surface-water inflow, and precipitation. Ninety-five percent of the nitrogen that entered the wetland (1974 through 1976) entered in ground-water inflow, which included the hatchery discharge. Two percent was from precipitation, and 3 percent entered in surface-water inflow. Sixty-six percent of the phosphorus input was from ground water, 31 percent from surface water, and 3 percent from precipitation. Some nutrients were retained because only 79 percent as much nitrogen and 93 percent as much phosphorus left the wetland in streamflow as entered it. 
Sediment was also retained. Only 20 percent as much sediment ( 1974 through 1976) left the wetland in streamflow as entered it. Sediment was deposited where surface-water inflow from upland areas flowed onto the wetland surface and along stream channels.

Inflows and outflows are quantified, and nutrient and sediment sources are identified, with the result that the effect of proposed land-use changes in the basin can be evaluated. Land-use practices that affect the wetland include drainage, urbanization, and water-supply development. Additional ground-water supplies can be obtained in the basin, but springflow and upward leakage of ground water through the organic soils will decrease.

\section{INTRODUCTION}

The Nevin wetland lies on the south edge of Madison, Wis. It is the headwaters of Nine Springs Creek.

The wetland is affected by local activities and those on the adjoining upland. Locally, stream channels have been straightened, probably as part of a drainage program. The Nevin State Fish Hatchery uses springflow and flow from artesian wells for rearing fish and then discharges the waste water into the wetland. Most of the surrounding uplands have been developed for agriculture, and urban areas are encroaching, particulariy from the north and west.

There is concern that the fish-hatchery operation and other activities on the upland may degrade the quality of water entering the wetland, modify the available water supply, and increase the amount of sediment and nutrients carried into it by overland flow.

\section{Purpose}

There is little information available on the hydrology of wetlands and how they interact with the hydrologic system. This study provides information on the hydrology of the Nevin wetland that should be valuable in its management and also may be useful in evaluating similar areas.

The report describes the hydrology of the Nevin wetland site. It describes the quantity and quality of water entering and leaving so that the effect of proposed or projected changes in land use, drainage, nutrient or sediment input, municipal or local pumpage, and hatchery operation can be compared and evaluated.

The project boundary was selected by Wisconsin Department of Natural Resources personnel to minimize the complexities of the system. The area of expanding urban development just north of the Nevin State Fish Hatchery was intentionally excluded. The study did not specifically consider the effect of intense urban development on the wetland, but the results may be used to evaluate these impacts in general. 


\section{Scope}

A water budget was based on 3-years' record of flow into and out of the wetland. Precipitation, pan evaporation, temperature, humidity, and wind velocity were observed daily during the warm months. Continuous records of stream stage provided information on surface-water inflow from adjoining uplands, springflow, discharge from the hatchery, and streamflow leaving. Flow-net analysis provided an estimate of the amount of ground water passing beneath the wetland in the underlying sand and gravel.

A comparison of sediment carried in to that carried out in streamflow indicated the amount of sediment retained. Sediment was sampled monthly at spring sites, below the hatchery discharge, and at the outflow site. Sediment was sampled daily from surface water entering during snowmelt or storms. Sediment samples were analyzed at the U.S. Geological Survey's Wisconsin sediment laboratory.

A comparison of dissolved material in inflow with that in outflow indicated the amount of dissolved material retained. Samples were obtained monthly in the stream, from springs, and from wells. Samples of surfacewater inflow were obtained at each site during individual snowmelt or storm occurrences.

\section{Acknowledgments and Cooperation}

This study was made by the U.S. Geological Survey in cooperation with the Wisconsin Department of Natural Resources (DNR). DNR Bureau of Research personnel at the Nevin State Fish Hatchery regularly obtained weather data, read gages, and collected sediment and water-quality samples. The DNR bureau laboratory at Delafield analyzed most of the water-quality samples.

\section{PHYSICAL SETTING}

The study area is a drainage basin of 580 acres, including 460 acres of upland and 120 acres of wetland (fig. 1). Linde (1973) has prepared a detailed map of the study area that is available. at the Nevin State Fish Hatchery. The 120-acre Nevin wetland forms the upper part of a larger, 320-acre wetland that extends northeastward along Nine Springs Creek. An intermittent stream enters from the south. Small springs occur around the edges. Their discharge has cut several channels that join to become the main channel of Nine Springs Creek. Nine such tributary channels enter the main stream within the study area, and a loth intermittent tributary enters just downstream.

Land cover on the 460-acre upland consists of approximately 160 acres of woods; 160 acres of croplands; 70 acres of grassland or pasture; and 70 acres of lightly used roads and parking areas, the hatchery buildings, and a few houses. 

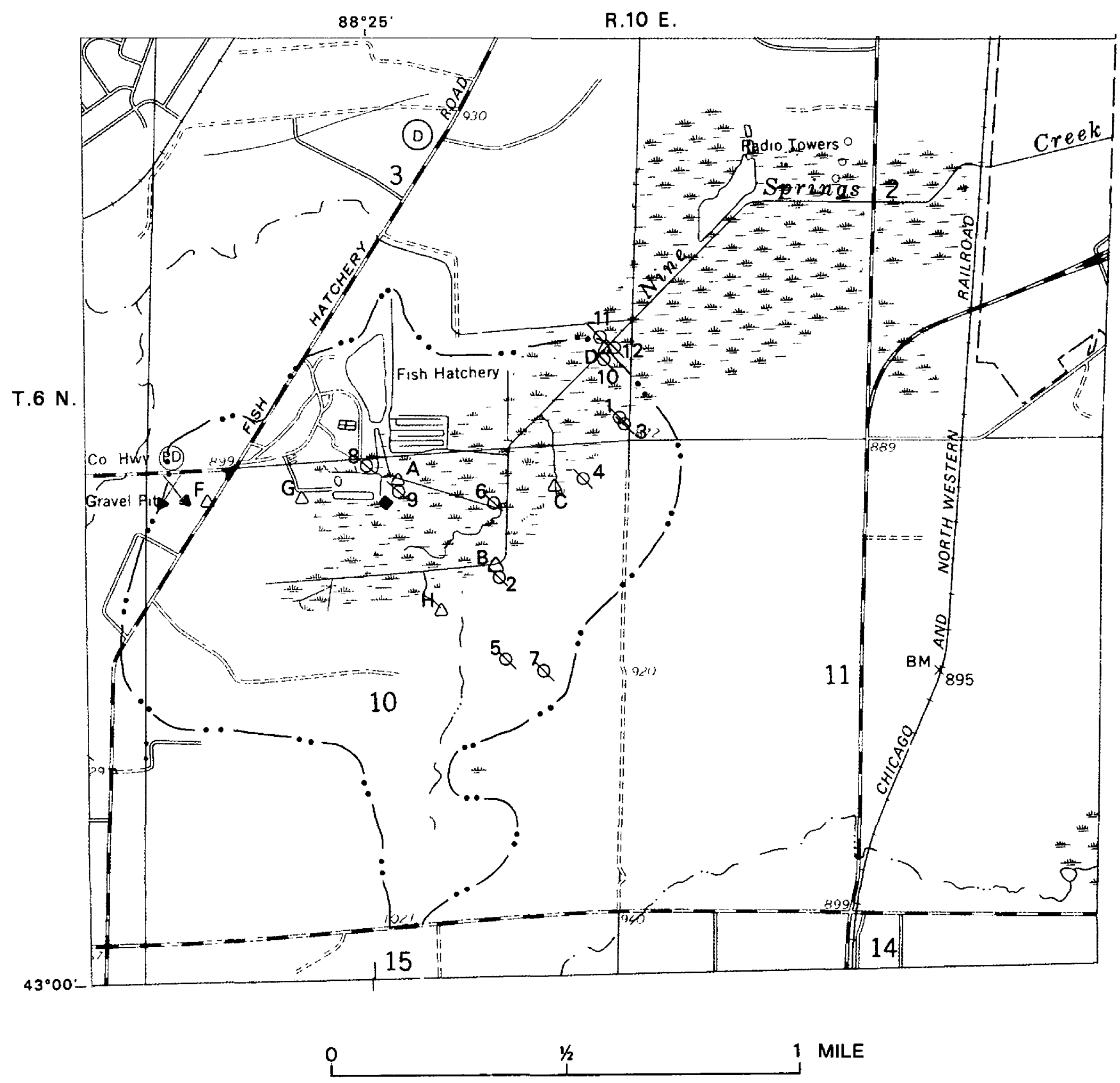

\section{EXPLANATION}

$\begin{array}{cc}\mathrm{B}_{\Delta} \quad \begin{array}{c}\text { Stream-gaging stations } \\ \text { Letter refers to locations } \\ \text { mentioned in text }\end{array} \\ \begin{array}{c}\text { Observation well } \\ \text { Number refers to locations } \\ \text { mentioned in text }\end{array} \\ \text { Weather station } \\ \cdots & \text { Basin boundary }\end{array}$

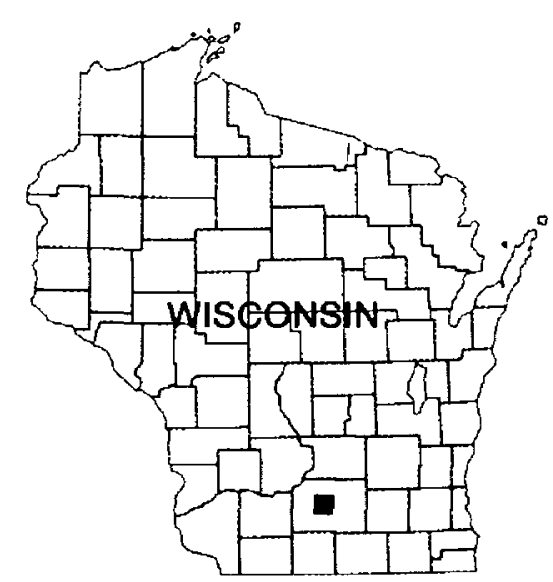

Figure 1. Nevin wetland and location of monitoring sites. 


\section{Wetland Characteristics}

The Nevin wetland is described as an "inland fresh meadow" according to the classification system given in Fish and Wildlife Circular 39 (Shaw and Fredine, 1956). It can be characterized as a "saturated, fresh water (alkaline), narrow-leafed emergent wetland on organic soil" according to the "Interim Classification of Wetlands and Aquatic Habitats of the United States" (Cowardin and others, 1976).

The organic wetland soils are kept nearly saturated by water discharging from the local ground-water system, but water rarely stands above the base of the plants. Some ponding occurred near site D (fig. 1) in March 1975, but was caused mostly by backwater from a flooding tributary just downstream from site D. Soil moisture (determined with a direct-reading moisture meter) ranged from 25 to 43 percent of wet weight (33 to 75 percent dry weight), even during the very dry summer of 1976. Frost is shallow during the winter, usually less than $1 \mathrm{ft}$ deep, apparently because of the circulation of warm $\left(10^{\circ}\right.$ to $\left.11^{\circ} \mathrm{C}\right)$ ground water and the insulation of organic soil.

Soil within the wetland is principally well-decomposed organic material. Fibrous material is rare. Granular material in the organic soil is derived from the mineral soil of adjoining uplands, which is transported into the wetland by water and wind. The organic soils are sandier near the edges.

The thickness of organic soil ranges from less than $1 \mathrm{ft}$ to $12 \mathrm{ft}$. The thickest accumulation of organic soil is in the south where it is from 3 to $12 \mathrm{ft}$ thick ( $\mathrm{fig}$. 2). In the north the organic soil is from 0 to $4 \mathrm{ft}$ thick.

Wetland vegetation is principally grasses and shrubs. Approximately 80 percent of the wetland is dominated by grasses and herbaceous plants, 10 percent by shrubs, and the remaining 10 percent includes woods and openwater areas (A. F. Linde, written commun., 1978).

\section{Hydrogeology}

The Nevin wetland is underlain by drift, which in turn is underlain by sandstone of Cambrian age. The drift lies in a valley eroded in the bedrock surface in preglacial time (fig. 3). The drift is composed of poorly sorted sandy glacial deposits. Some thin, discontinuous clay lenses from a few inches to several feet thick were found in several test holes. Near the basin edges the drift thins but it is more than 250 ft thick in the center. The underlying bedrock is Cambrian sandstone. Cline (1965) provides a general discussion of Dane County geology.

The ground-water basin that supplies water to the Nevin wetland is larger than the surface-water basin. The drift and the upper sandstone units constitute a hydrologic unit (McLeod, 1975, p. 11-12, table 1). A water-table map based on water-level data from shallow wells in drift and sandstone ( $\mathrm{fig}$. 4) defines a ground-water basin of approximately $17 \mathrm{mi}^{-2}$. Within this basin ground water moves from higher to lower levels to discharge 


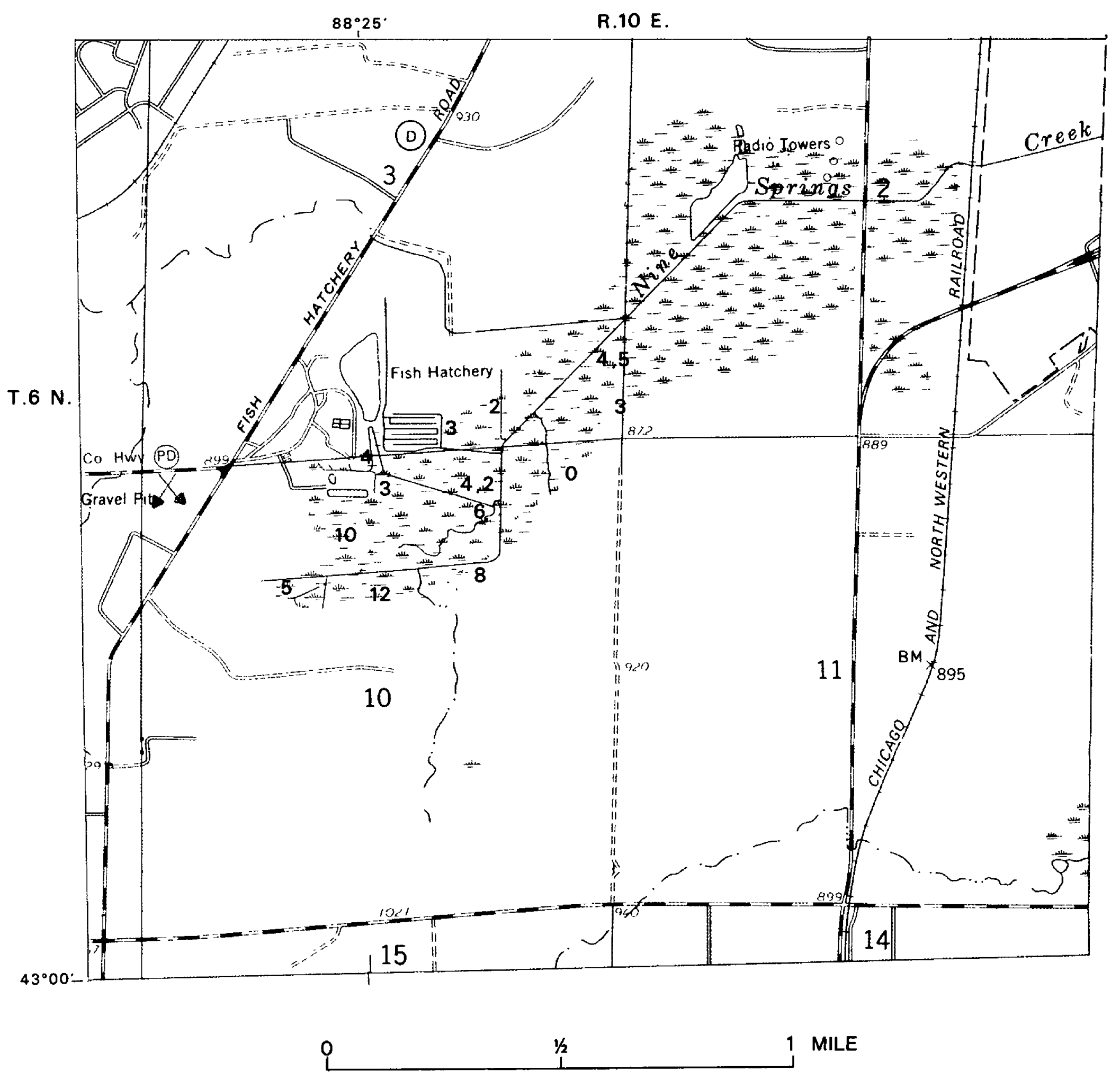

Figure 2. Thickness, in feet, of organic material. 


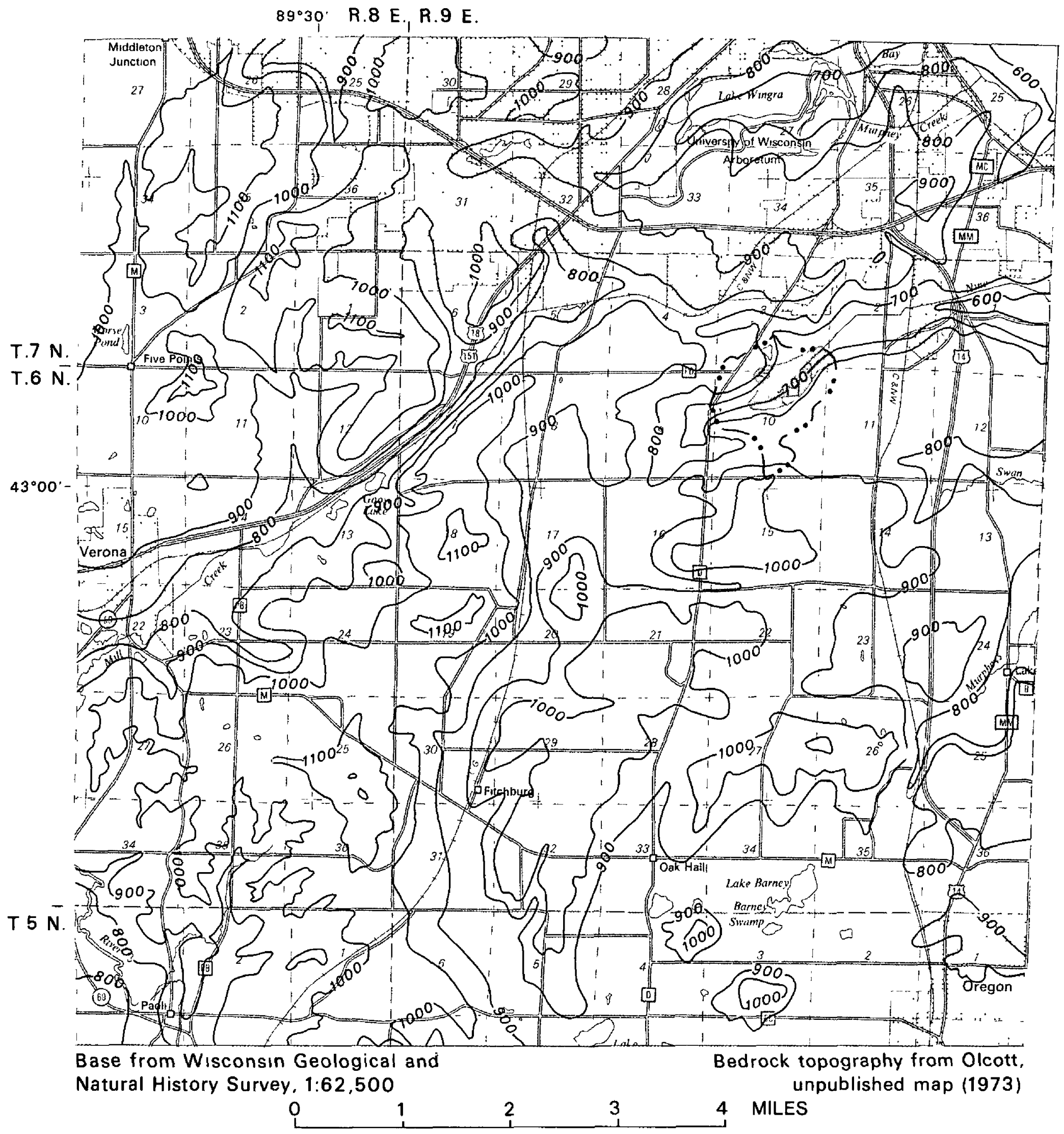

EXPLANATION

Bedrock contour
Shows altitude of bedrock surface
Contour interval 100 feet
Datum is mean sea level

Figure 3. Bedrock topography. 
within the Nevin wetland. The saturated part of the drift is from 0 to more than $200 \mathrm{ft}$ thick (fig. 5). This unit is confined (under artesian pressure) beneath the less permeable wetland deposits. A geohydrologic section through the area ( $f i g .5$ ) shows the wetland relative to the major elements of basin geology.

\section{HYDROLOGY}

The hydrologic system includes water in the atmosphere, on the land surface, and within the ground. The atmosphere provides precipitation onto the wetland and removes water evaporated or transpired. Some water flows overland into the wetland. Ground water discharges in the wetland area. Water leaves the wetland by evapotranspiration or it flows out of the wetland in Nine Springs Creek. The relationship between precipitation, surface water, and ground water determines the hydrologic characteristics of the wetland site. Water quality changes as the precipitation, overland flow, and ground water $\operatorname{mix}$. A water budget shows the relative importance of water from different sources. A budget of suspended and dissolved materials in the water shows how water quality changes within the wetland.

\section{Water Budget}

A water budget is a quantitative account of water inflow, outflow, and storage changes within the wetland. Precipitation, surface water, and ground water are inflows (fig. 6). Streamflow and evapotranspiration are outflows. Changes in water stored in the organic soils during the study were negligible, and were not included in the budget.

The water budget is based on the 3 years 1974 through 1976. Both 1974 and 1975 were years of more than average precipitation, and 1976 was less than average. However, the 3-year average is only 0.35 in less than the long-term average for the Madison area. Thus, the water-budget data summarized in table 1 reflect near-average conditions.

\section{INFLOW}

Inflow included precipitation, surface water, and ground water (fig. 6). Surface-water inflow was water that flowed overland. Ground-water inflow included the discharge of springs, wells (water used in the hatchery and then discharged into the wetland), and upward leakage through the organic soils. Precipitation was recorded during the warm months. Surface-water inflow was measured at three stream-gaging sites (sites F, G, and $\mathrm{H}, \mathrm{fig}$. 1). Ground-water inflow was partly measured (discharge from two major springs, sites $C$ and $H$, fig. 1 , and from the hatchery, site A, fig. 1) and partly estimated by subtracting all the known inflows from the basin outflow.

Precipitation.--During the study annual precipitation (fig. 6) averaged 29.9 in. Precipitation was recorded in the wetland during the warm months of 1974-76. These data were compared to data from the Madison weather station at Truax Field (NOAA, 1973-76) to fill periods of missing record 


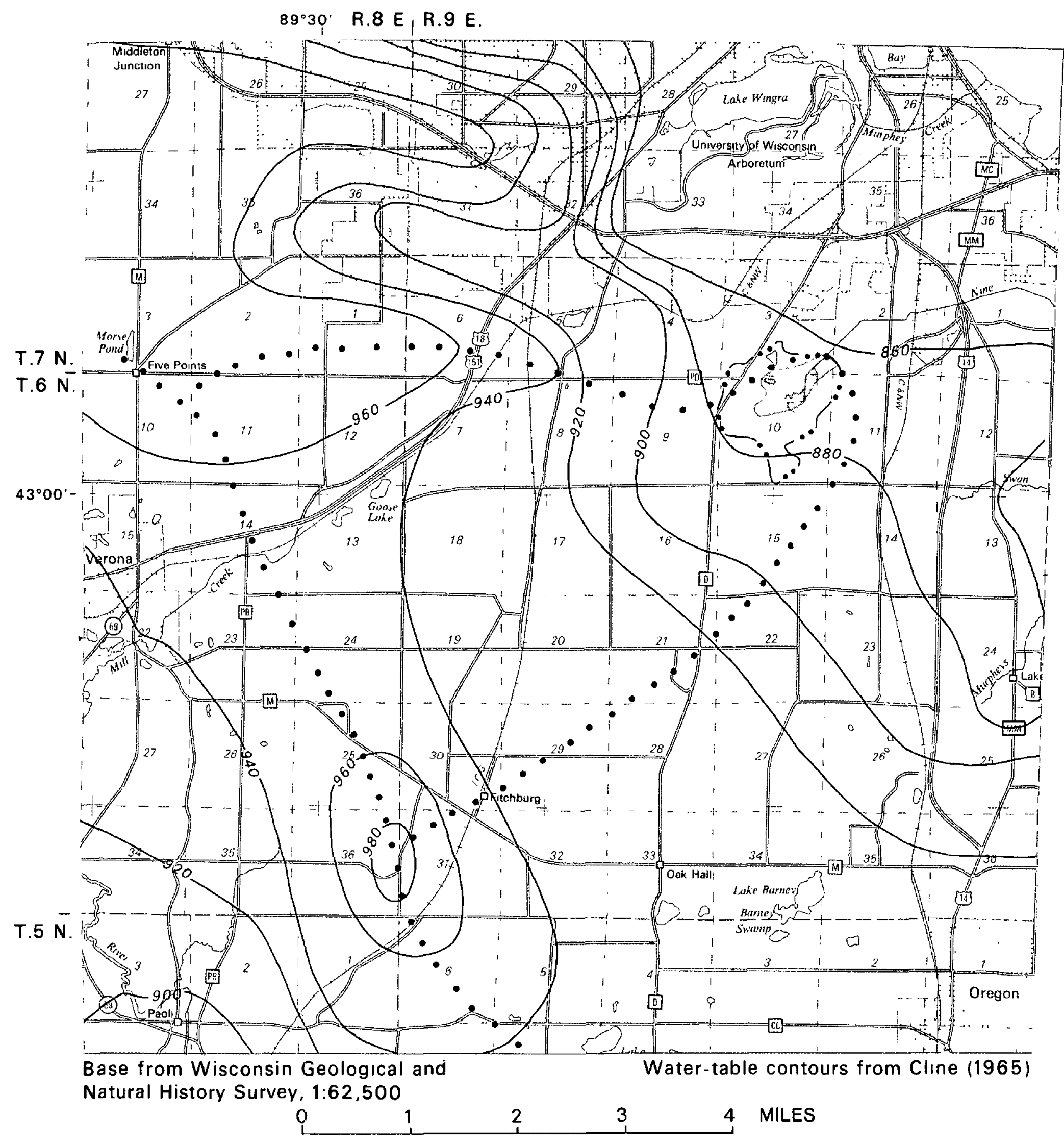

EXPLANATION
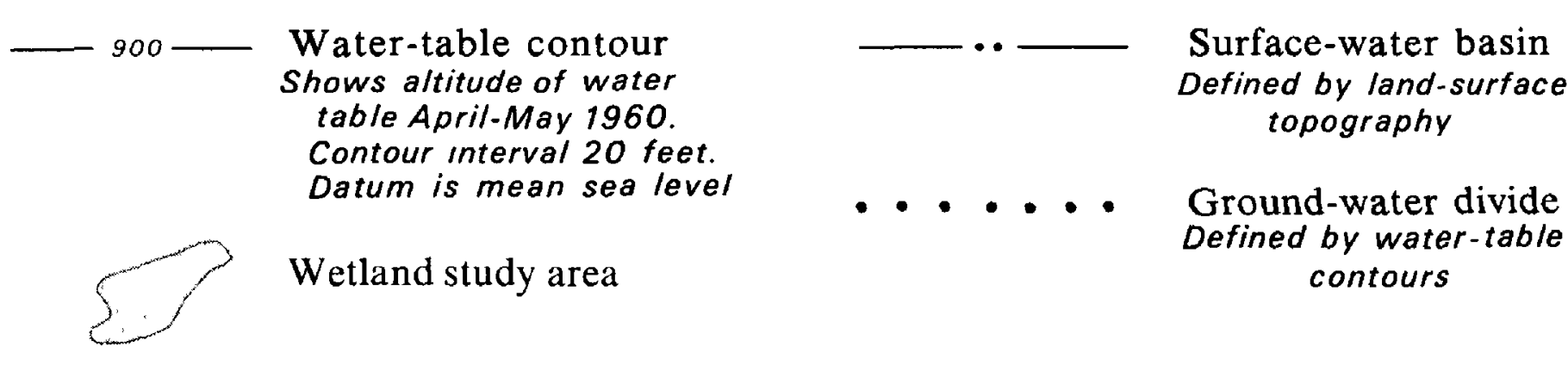

Ground-water divide

Defined by water-table contours

Figure 4. Water table. 


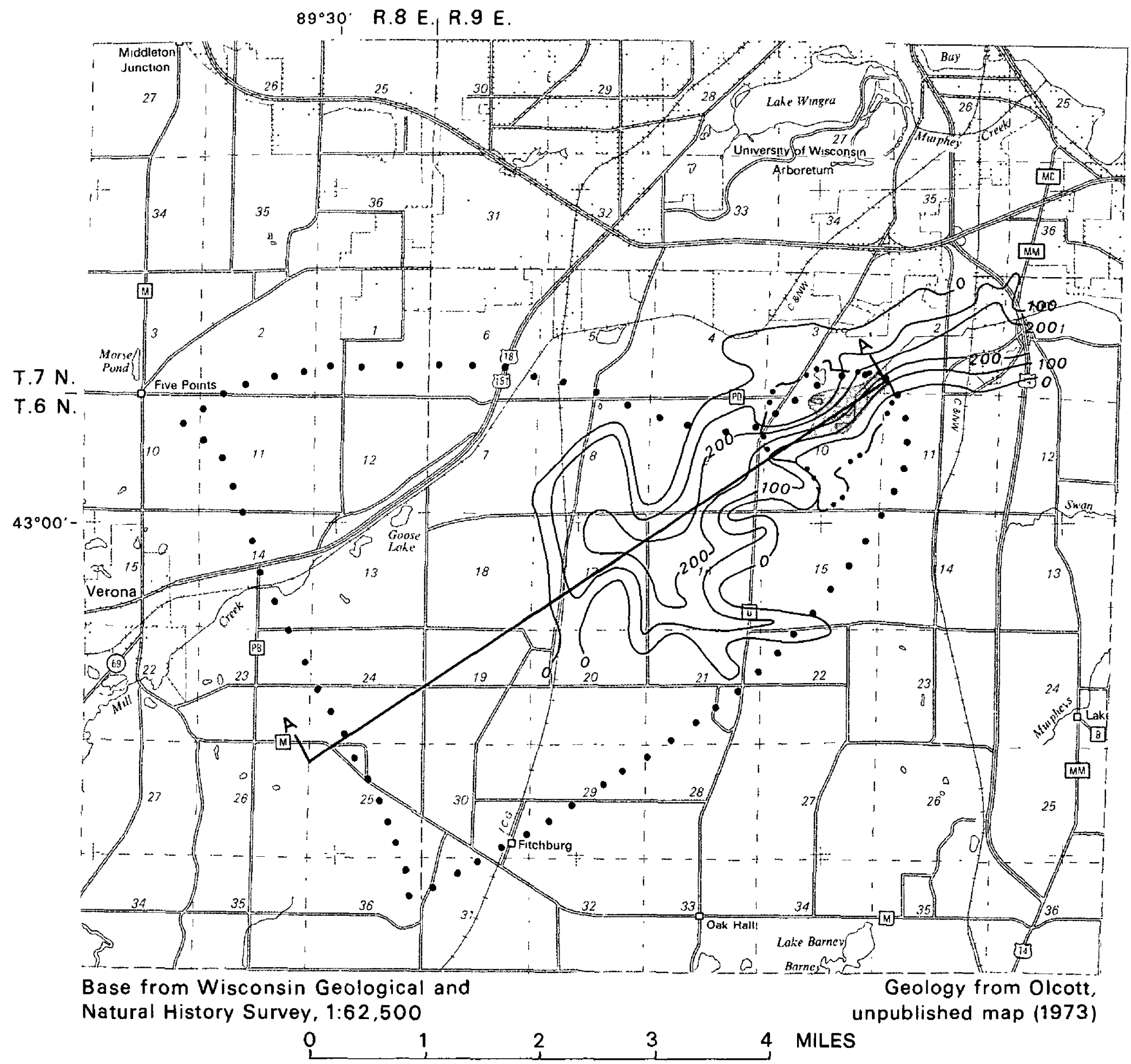

EXPLANATION

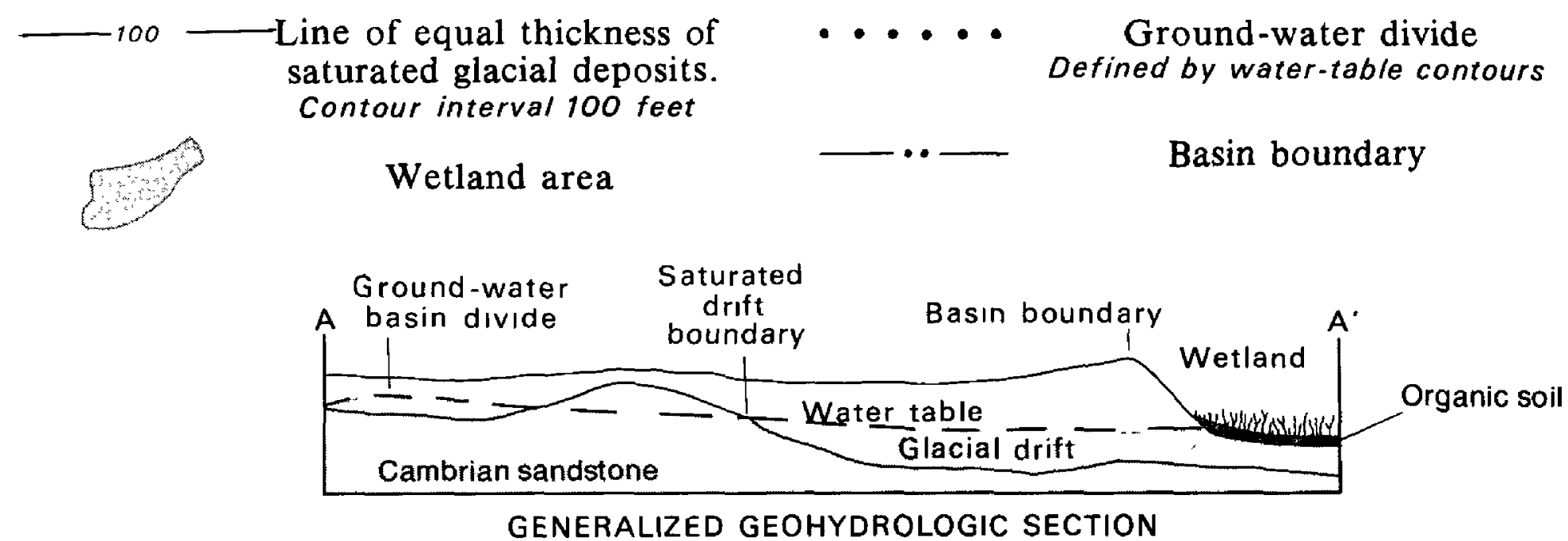

Figure 5. Thickness of saturated glacial deposits and generalized geohydrologic section. 


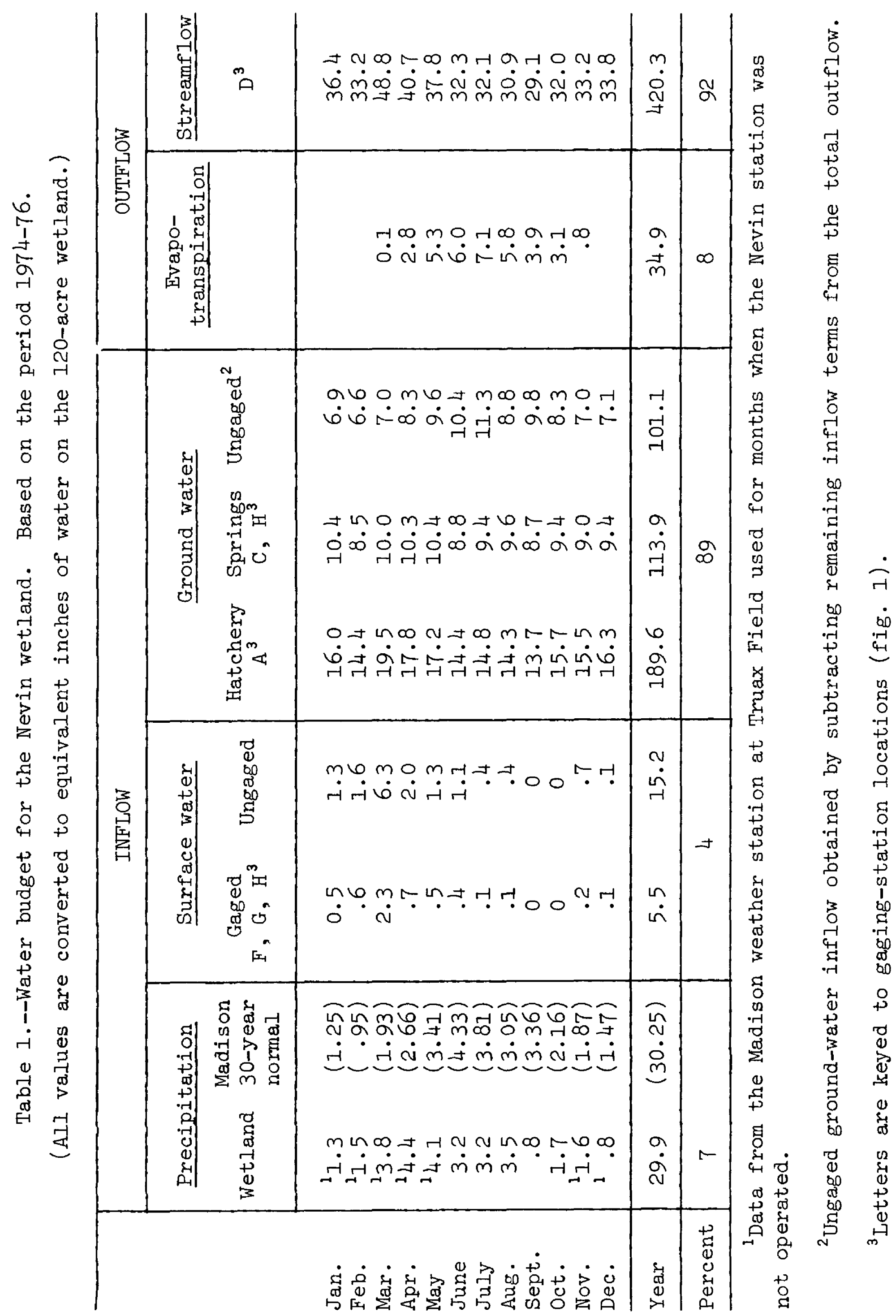




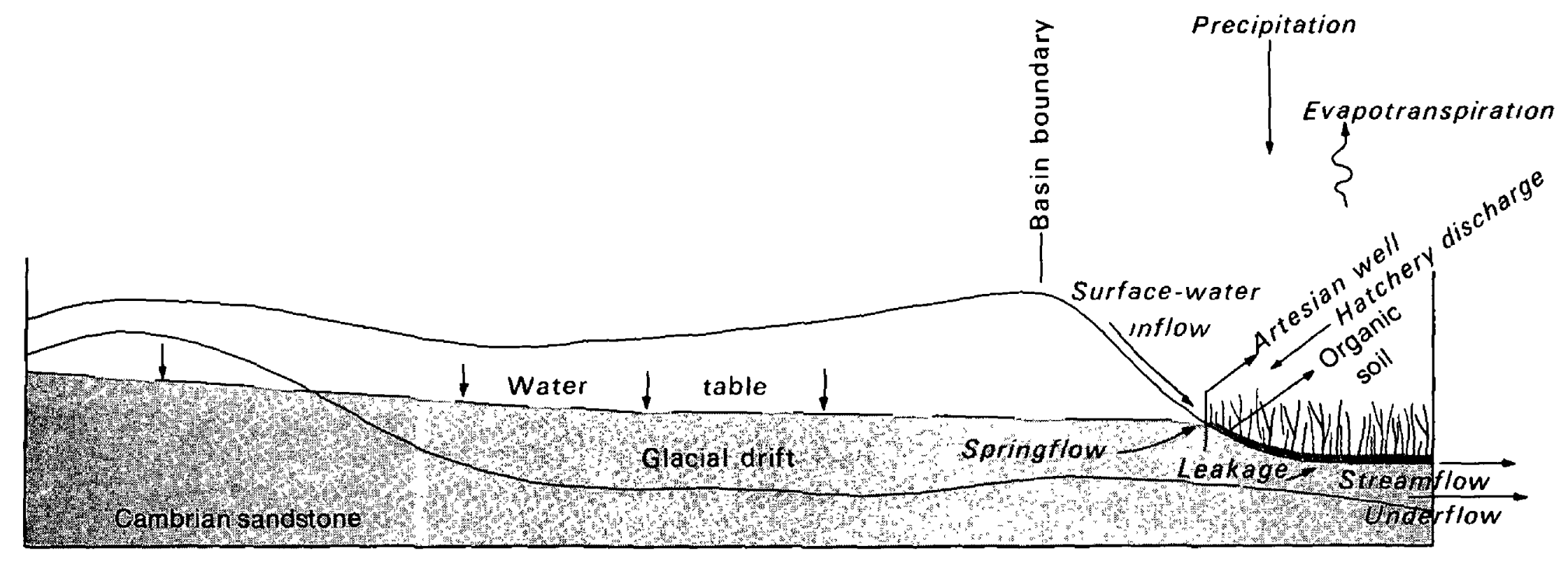

Figure 6. Diagrammatic sketch of the Nevin wetland's water budget elements related to basin geology.

and to provide information on long-term precipitation amounts. These 30year "normals" for the Madison station appear in parentheses in the precipitation column, table 1 .

Surface-Water Inflow.--Surface-water inflow (fig. 6) averaged only 20.7 in annually (table 1) because most precipitation readily infiltrated the sandy upland soils and little water ran off overland. Most surface-water inflow occured in early spring during snowmelt. Surface-water inflow was gaged at three locations--sites F, G, and H (fig. 1); these sites measure runoff from drainage areas of 19, 26, and 110 acres, respectively, or about onethird of the total upland area. Flow was intermittent at sites $F$ and $G$. Site $H$ was a spring site and springflow was continuous, so the surfacewater inflow reported for site $H$ was the flow observed during snowmelt or intense storms minus the normal springflow volume.

Annual surface-water inflow averaged 5.49 in at site $\mathrm{H}(0.05 \mathrm{in} /$ acre $)$ but was less than 0.05 in at sites $F$ and $G(0.0005$ in/acre). Gravel pits in the drainage basins for sites $F$ and $G$ retained precipitation, reduced overland flow, and increased infiltration, and these basins are not typical of most of the upland area. The basin above site $H$ is composed of 50 percent woods, 40 percent agricultural fields, and 10 percent grassland, and is 
representative of the remaining upland area, because these three cover types constitute 85 percent of the total upland basin (390 of 460 acres). Runoff measured at site $\mathrm{H}(0.05 \mathrm{in} / \mathrm{acre})$ was used to estimate surface-water inflow ( 15.2 in annually) from the ungaged upland area (305 acres).

Ground-Water Inflow.--Ground-water inflow was from springs, artesian wells, and upward leakage through the organic soils (fig. 6).

Springs.--Gaging stations at sites $\mathrm{C}$ and $\mathrm{H}$ monitored the flow from two springs ( $f i g .1$ ). The springflow was relatively constant and averaged 113.9 in annually (table 1). Many minor springs were present but were not monitored during this study.

The Nevin hatchery used water from springs and from artesian wells penetrating the drift aquifer. This water was released above site A. Water from the hatchery (monitored at site A) averaged 189.6 in annually (table 1).

Upward Leakage.--Ground-water inflow occurring as upward leakage through the organic soil in the wetland ( $f i g .7$ ) could not be measured directly. Ungaged inflow, including discharge from ungaged springs as well as upward leakage, was estimated as the difference between the measured outflow and measured inflow. Ungaged inflow averaged 101.1 in annually (table 1).

Water-temperature differences along the stream channels indicated areas of significant ground-water inflow (Novitzki, 1973, p. 6, p. 28, and p. 46-52). Upward leakage occurred throughout the wetland, but was somewhat less in the south-central and the northern parts of the area (fig. 7). In the south-central area ground water that formerly leaked upward through the organic soil and discharged to the original stream channel is now captured by the straightened and deepened channels to the north and south. (Lessened ground-water inflow in this area may be partly because of the greater thickness of organic soil (fig. 2).) On the north side of the wetland straightened and deepened stream channels within the wetland apparently captured ground water that formerly leaked upward through the organic soil near the wetland's edge.

\section{OUTFLOW}

Outflow occurred as streamflow and as evapotranspiration (evaporation plus plant transpiration) (fig. 6). Streamflow was gaged at site D throughout the study. Pan evaporation was recorded daily during the warm months. Evapotranspiration was estimated on the basis of recorded pan-evaporation data.

Streamflow.--Streamflow leaving the study area (fig. 6) was 420.3 in annually (table 1). It peaked during early spring and decreased through the summer as evapotranspiration increased, reaching a low in September. 


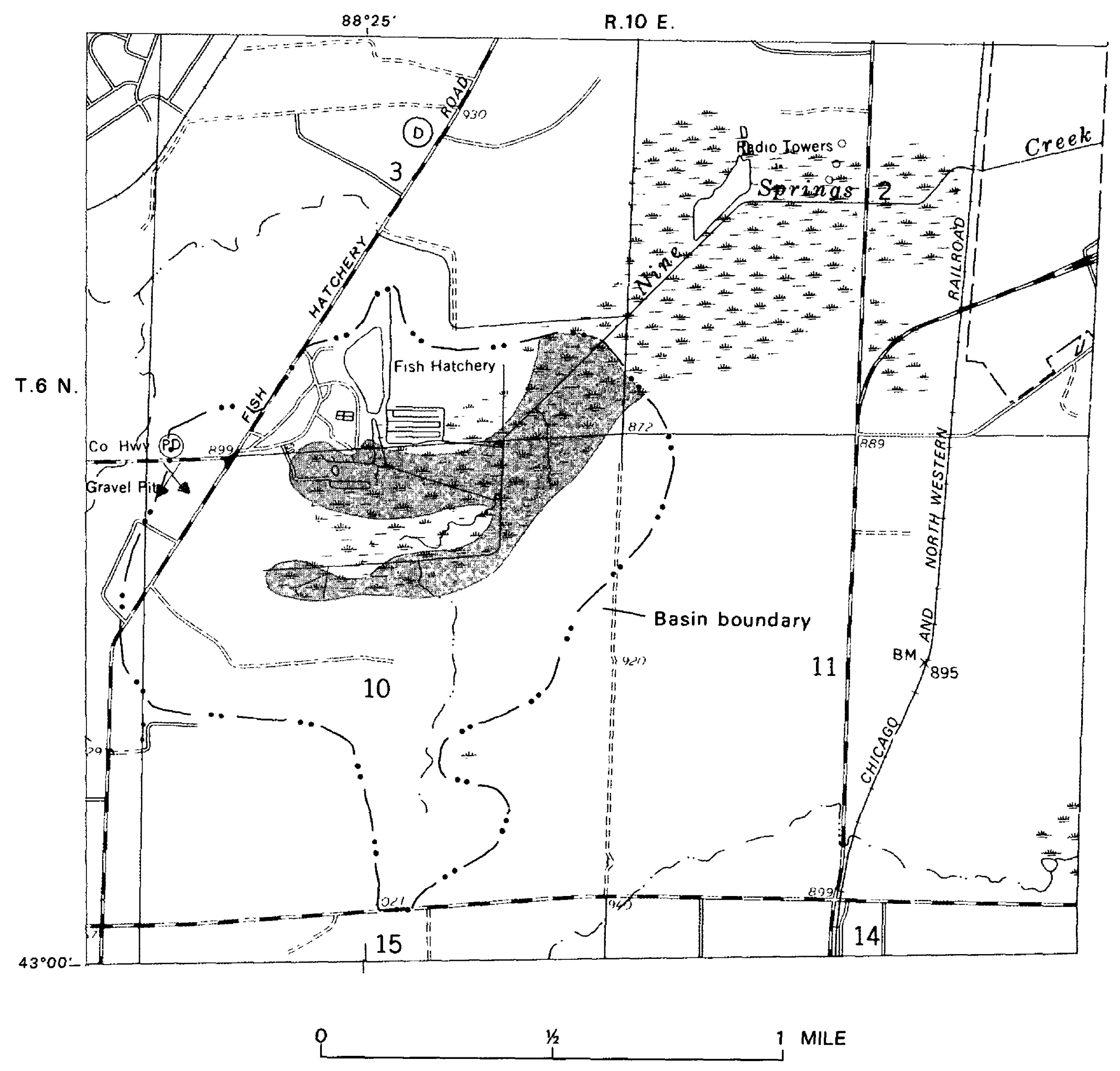

Figure 7. Area where stream temperatures indicate significant ground-water discharge. 
Evapotranspiration.--Evapotranspiration (ET) (fig. 6) usually occurred at the potential maximum rate in the wetland and averaged 34.9 in annually (table 1). Evapotranspiration was determined from pan evaporation recorded within the wetland. Studies by Sturges (1968) in Wyoming and by Bay (1966) in Minnesota showed that evapotranspiration in wetlands where water is available throughout the growing season usually equals or exceeds (by as much as 27 percent) measured pan evaporation. No information was available to adjust pan evaporation measured in the Nevin wetland, so evapotranspiration was assumed equal to pan evaporation, although this value may be 10 to 20 percent lower than actual evapotranspiration.

Evapotranspiration from the wetland was greatest in 1976, when ET from the uplands was least. Air masses moving across the wetland were considerably drier in 1976 because evapotranspiration from the upland area (estimated using the Thorthwaite and Mather (1957) technique) was only 14.2 in in 1976, compared to 20.6 and 23.3 in in 1974 and 1975 , respectively. The drier air masses in 1976 apparently could transport more moisture, and evapotranspiration from the wetland area was 39.9 in compared to 31.3 and 33.5 in in 1974 and 1975, respectively.

\section{CHANGE IN STORAGE}

Changes in the amount of water stored in organic soil were negligible. The soils were nearly saturated except in the peak growing season, when maximum evapotranspiration occurs. Soil moisture, measured with a directreading soil-moisture meter, ranged from 25 percent of wet weight (33 percent dry weight) to 43 percent of wet weight ( 75 percent dry weight). This moisture range of 18 percent of wet weight represents a change of less than 1 in of water, indicating a negligible change in water stored in the soil. Storage changes were not included in table 1 .

\section{Underflow}

Underflow (fig. 6) was ground water that moved beneath the wetland without entering it. It was not part of the water budget, but indirectly affected springflow, seepage, and outflow. The underflow discharged to the rest of the wetland east of the study area, to Nine Springs Creek, and finally to the Yahara River system.

Underflow was estimated from water-table gradients, hydraulic conductivity, and cross-sectional area of the drift aquifer beneath the wetland deposits. Underflow is estimated to be 30.6 in annually. Darcy's Law was used to estimate underflow as the gradient multiplied by hydraulic conductivity multiplied by area. (Gradient $=15 \mathrm{ft} / \mathrm{mi}(0.003 \mathrm{ft} / \mathrm{ft}$ ), hydraulic conductivity $=260(\mathrm{gal} / \mathrm{d}) / \mathrm{ft} 2\left(\right.$ McLeod, 1975, p. 21), area $=350,000 \mathrm{ft}^{2}$, and computed underflow $=36,500 \mathrm{ft} 3 / \mathrm{d}$, or the equivalent of 30.6 in per year.) Total underflow is somewhat greater than this because some water moves through the upper part of the underlying sandstone, but because underflow is not part of the water budget for the study area, this estimate was not refined. 


\section{Water Quality}

A comparison of dissolved material in inflows and outflows defined water-quality changes occurring in the wetland.

\section{PRECIPITATION}

Precipitation contained little dissolved material. Precipitation was not analyzed during this study, but previous analyses by Hindall (written commun., 1977), Peterson (written commun., 1977), and Kluesener (1972) indicate that all dissolved constituents except bicarbonate are considerably lower in precipitation than in other water sources (table 2). Precipitation contributed 2 percent of the nitrogen, 3 percent of the phosphorus, and none of the sediment entering the wetland (table 3 ).

\section{SURFACE-WATER INFLOW}

Surface-water inflow during snowmelt or storms may have high concentrations of suspended and dissolved materials (table 2). Maximum sodium and chloride concentrations in surface-water inflow were considerably higher than in other water sources. Apparently they were caused by large amounts of road salt contained in runoff from roads salted during the winter. Phosphorus concentrations in surface-water inflow also were higher than in other inflow sources. Apparently these higher concentrations were caused by large amounts of fertilizer residue contained in runoff from fertilized croplands. Surface-water inflow contributed 31 percent of the phosphorus entering the wetland (table 3). Of this amount, 1 percent was from the areas above sites $F$ and $G$, representative of the part of the basin containing a few homes and the hatchery buildings, and 30 percent is estimated to be from the undeveloped and agricultural part of the basin (site $H$ and ungaged areas). Surface-water inflow contributed only 3 percent of the nitrogen entering the wetland. Sediment concentrations in surface-water inflow were considerably higher than in other water sources, averaging $62.5 \mathrm{mg} / \mathrm{L}$ (milligrams per liter) (table 2). However, sediment yields from areas above sites $F$ and $G$, where gravel pits and other modifications in the basins apparently have created efficient sediment traps, were negligible. Estimates of sediment from ungaged areas were based on data from site $\mathrm{H}$. Surface-water inflow contributed 96 percent of the total sediment entering the wetland (table 3).

\section{SPRINGFLOW AND LEAKAGE}

Water samples from springs and wells represent local ground water (table 2). Concentrations of constituents in springs varied because some surface water was included in the samples during snowmelt or storms. However, the average values represent ground-water conditions. The flow from springs also contained sediment that originated in ponds and channels. This sediment was included under surface water (tables 2 and 3 ). Ground water contributed 95 percent of the nitrogen and 66 percent of the phosphorus entering the wetland (table 3 ). 


\section{HATCHERY DISCHARGE}

Water discharged from the hatchery, sampled at site $A$, was similar to spring and well water (table 2). The hatchery discharge was 47 percent of the total ground-water inflow (189.6 divided by 404.6, table 1). The hatchery discharge contained 48 percent of the phosphorus ( 32 divided by 66, table 3) and 34 percent of the nitrogen contained in ground-water inflow (32 divided by 95, table 3). The hatchery operation apparently did not increase dissolved material in the water it used. The flow past site A contained 4 percent of the sediment entering the wetland. However, the sediment probably came from the hatchery grounds rather than from the hatchery operation.

The results from this study indicate that the hatchery operation does little to affect the quality of water entering the wetland. However, a more detailed study could define changes in water chemistry that may occur during the hatchery operation between the entry and discharge points. Such detailed work was beyond the scope of this study.

\section{SURFACE-WATER OUTFLOW}

The concentrations of dissolved materials in the streamflow leaving the wetland was similar to that in the ground-water inflow (springs, wells, and the hatchery discharge (table 2)). However, the amount of suspended and dissolved material leaving in streamflow was less than the amount that entered.

\section{EFFECT OF WETLAND ON WATER QUALITY}

The wetland reduced the amount of suspended material in the water moving through it (table 3). Only 19 percent of the sediment that entered left in the surface-water outflow. The remaining 81 percent was retained. Most of this sediment was deposited near the edges where surface-water inflow flowed onto the relatively flat wetland surface and flow velocities decreased. There, and along the stream channels, lenses of sand- and siltsized particles are found within the organic soil.

The wetland also reduced the amount of dissolved nutrients in the water moving through it (table 3 ). Only 79 percent as much nitrogen and 93 percent as much phosphorus left in the surface-water outflow as entered; the rest apparently was retained. The nutrient budgets are approximate, but indicate the relative contribution from different sources and may be used to evaluate the impact that changing these inputs might have on the wetland.

Study results did not identify either physical or biological retention mechanisms operating in the wetland. Sediment deposition is a physical process. However, nutrient reduction may be a physical process (related to sediment deposition), a biological process (related to plant utilization), or a combination of the two. More detailed studies could define these mechanisms. 
Table 2.--Chemical characteristics of water from different sources in the Nevin wetland ${ }^{1}$

(Values are in milligrams per liter except $\mathrm{pH}$ and conductance, which are in standard units.)

\begin{tabular}{|c|c|c|c|c|c|c|}
\hline & \multicolumn{3}{|c|}{$\frac{\text { Precipitation }}{(60 \text { samples })^{1}}$} & \multicolumn{3}{|c|}{$\frac{\text { Surface-water inflow }}{(7 \text { samples })}$} \\
\hline & Min & $\operatorname{Max}$ & Mean & Min & $\operatorname{Max}$ & Mean \\
\hline Total nitrogen & 0.02 & 4.40 & 1.50 & 2.20 & 5.39 & 3.46 \\
\hline Total phosphorus & 0 & .69 & .06 & .69 & .86 & .78 \\
\hline Calcium ( $\mathrm{Ca}$ ) & .30 & 37 & 2.48 & 3 & 35 & 11 \\
\hline Magnesium (Mg) & 0 & 30 & 1.98 & 2 & 31 & 9 \\
\hline Sodium (Na) & 0 & 5 & 1.14 & 1 & 156 & 38 \\
\hline Potassium (K) & .20 & 5.40 & .77 & 1.1 & 3.7 & 2.3 \\
\hline Sulfate $\left(\mathrm{SO}_{4}\right)$ & 2.6 & 8.8 & 5.86 & 19 & 35 & 25 \\
\hline Chloride (Cl) & 0 & 30 & 2.02 & 3 & 195 & 66 \\
\hline Bicarbonate $\left(\mathrm{HCO}_{3}\right)$ & 0 & 17 & 8.22 & 2 & 13 & 8 \\
\hline $\mathrm{pH}$ & 4.7 & 7.4 & 6.10 & $7 \cdot 3$ & 7.7 & 7.6 \\
\hline Conductance & 20 & 70 & 43 & 76 & 797 & 327 \\
\hline Sediment & --- & ---- & $-\cdots-$ & 1 & 10,350 & 62.5 \\
\hline
\end{tabular}

${ }^{1}$ Precipitation data from studies conducted elsewhere in Wisconsin by Hindall (written commun., 1977), Peterson (written commun., 1977), and Kluesener (1972). 
Table 2.-Chemical characteristics of water from different sources in the Nevin wetland

(Values are in milligrams per liter except $\mathrm{pH}$ and conductance, which are in standard units.)

\begin{tabular}{|c|c|c|c|c|c|c|c|c|}
\hline Spr & $\begin{array}{l}\text { ags and } \\
5 \text { sampl }\end{array}$ & $\begin{array}{l}\text { Ground- } \\
\text { sells } \\
\text { s) }\end{array}$ & $\begin{array}{r}\text { Hatcl } \\
(37\end{array}$ & $\begin{array}{l}\text { ry disc } \\
\text { samples }\end{array}$ & large & & Outflow & \\
\hline Min & $\operatorname{Max}$ & Mean & Min & $\operatorname{Max}$ & Mean & Min & $\operatorname{Max}$ & Mean \\
\hline 0.79 & 13.28 & 6.27 & 1.40 & 10.66 & 5.01 & 1.96 & 11.79 & 5.42 \\
\hline .01 & .53 & .07 & .01 & .21 & .10 & .01 & 1.32 & .14 \\
\hline 8 & 119 & 66 & 6 & 110 & 56 & 21 & 131 & 64 \\
\hline 4 & 142 & 45 & 4 & 142 & 41 & 6 & 142 & 46 \\
\hline 1 & 20 & 6.3 & 2 & 20 & 7.4 & 3 & 21 & 7.2 \\
\hline .5 & 9.9 & 1.8 & .5 & 7.5 & 2.1 & .5 & 10.7 & 2.3 \\
\hline 9 & 44 & 23 & 9 & 35 & 23 & 4 & 41 & 25 \\
\hline 3 & 15 & 10 & 5 & 17 & 12 & 5 & 38 & 11 \\
\hline 8 & 67 & 52 & 27 & 58 & 50 & 28 & 57 & 51 \\
\hline 7.4 & 8.6 & 7.9 & 7.6 & 8.6 & 8.0 & 7.6 & 8.6 & 8.1 \\
\hline 96 & 750 & 549 & 470 & 632 & 534 & 446 & 703 & 550 \\
\hline--- & -- & $--\cdots$ & 0 & 109 & 13.3 & 1 & 145 & 24.9 \\
\hline
\end{tabular}




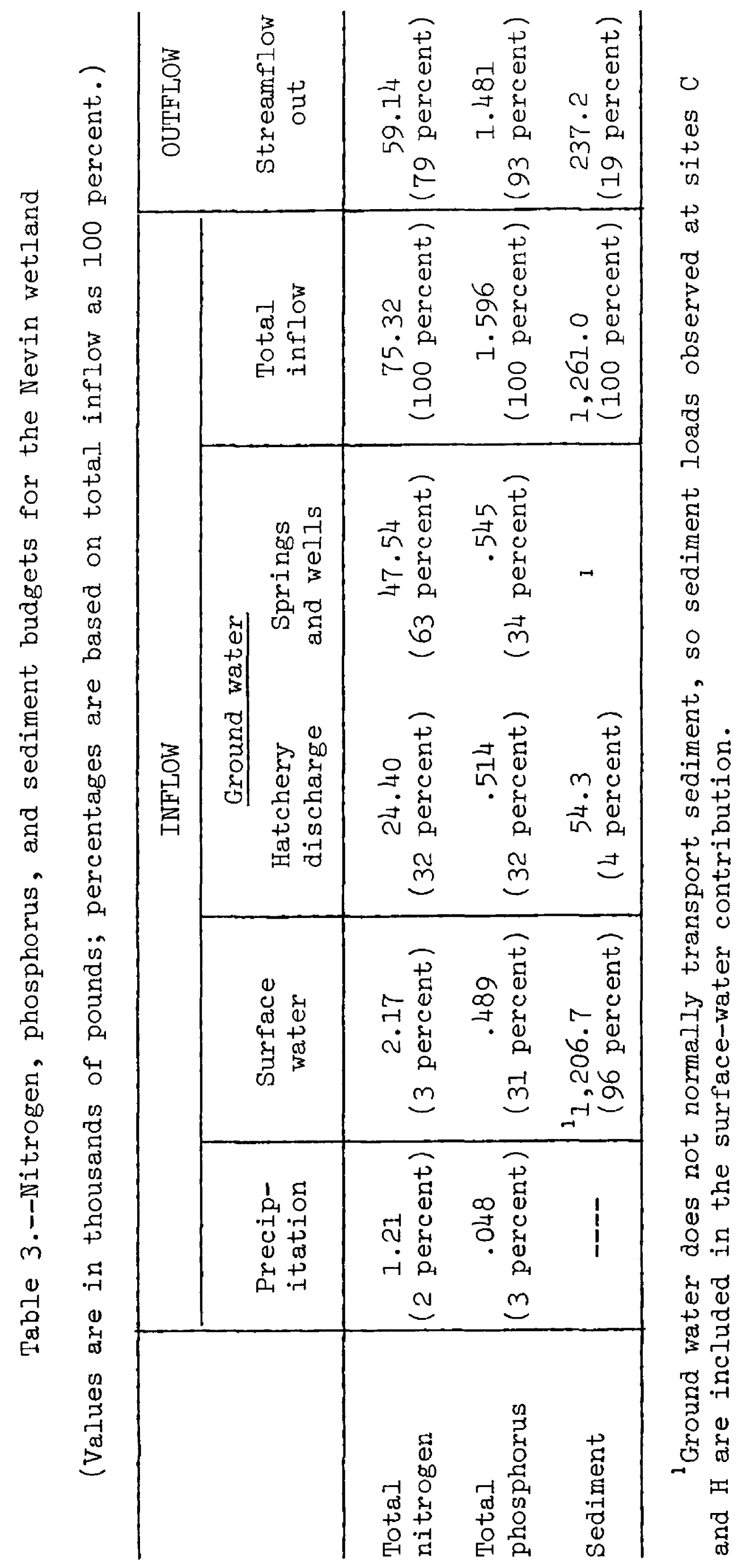




\section{FACTORS AFFECTING THE WETLAND}

Several activities and land-use practices influence current conditions and changing them may cause changes in the wetland. The Nevin hatchery is conspicuous because it discharges water to the wetland, but it seems to have little influence. Runoff from agricultural areas transports significant amounts of sediment and nutrients. Developed areas, including homes, buildings, roads, and parking areas, occupy 11 percent of the basin, but runoff from these areas is minimal and the amount of sediment and nutrients transported is negligible.

\section{Hatchery}

The hatchery discharge sampled at site A had characteristics similar to water sampled from wells and springs (table 3 ). Chemicals added to the water during hatchery operations are a potential source of contamination, but monthly sampling and analysis for common ions and nutrients at site $A$ during the study was not adequate to indicate contamination. Further, analysis of a single sampling of bottom sediments (where pesticide residuals tend to accumulate) at site $A$ revealed no evidence of 20 different organic compounds commonly contained in chemical pesticides. And finally, sediment concentration was lower in the hatchery effluent than at other points in the wetland. Although the hatchery discharge appeared to have little effect, a detailed study would be needed to identify changes in water chemistry occurring within, and directly caused by, the hatchery operation.

The hatchery discharge enters a stream channel, and changing water quality within stream channels had little effect on the rest of the wetland except during floods.

\section{Surface-Water Inflow from Agricultural and Undeveloped Areas}

Surface-water inflow from agricultural lands and undeveloped areas carried sediments and nutrients. Phosphorus concentrations in samples taken at site $\mathrm{H}$ (agricultural and undeveloped areas) during runoff were 10 times as great as those in ground-water sources and were several times greater than those in samples from sites $F$ and $G$ (developed areas). However, nitrogen concentrations were similar to or less than those from groundwater sources. The probable source of these nutrients was residues from fertlizer applied to croplands. Agricultural lands also are potential sources of pesticides. However analyses of a single sampling of bottom sediments (where pesticide residuals tend to accumulate) from sites $B$ and $D$ for 20 organic compounds commonly contained in pesticides were all negative. The agricultural and undeveloped upland areas yielded 96 percent of the total sediment load to the wetland and most of this originated from cultivated areas.

Surface-water inflow usually flowed directly into stream channels within the wetland, and had little effect beyond the stream channels except during flooding. Surface-water inflow that does not flow directly into channels, however, will have more direct influence on the wetland areas covered. 


\section{Surface-Water Inflow from Developed Areas}

Surface-water inflow from areas containing homes, the hatchery buildings, and lightly used roads and parking areas carried suspended and dissolved materials into the wetland. Surface-water inflow from these areas represented only a small part of the water budget, however, and the amounts contributed are small. Only about 70 acres of the 580-acre basin were developed, primarily as buildings at the Nevin hatchery and DNR headquarters area, as residences, as road surfaces, and as gravel pits at the west edge of the basin. The gravel pits detained water, allowing infiltration. Paved areas and rooftops increased runoff, but these are small areas interspersed within grassy or wooded land, so runoff remained minimal. Road salt in runoff from roadways caused sodium and chloride concentrations observed at sites $F$ and $G$ (runoff from developed areas) to be considerably higher than concentrations at site $H$ (runoff from agricultural and undeveloped areas). However, the flow at sites $F$ and $G$ was less than 0.05 in per year and the contribution of dissolved material from these basins was negligible.

Similarly, sediment concentrations at sites $F$ and $G$ were high (though less than those at site $\mathrm{H}$ ), but because total flow is small, the sediment load from those two basins was negligible.

\section{Land-Use Changes}

Land-use changes in the basin may affect the wetland. An evaluation of the impact of land-use changes was beyond the scope of this study. However, some activities may modify the hydrology of the wetland area, or change the character of the water entering it. These activities include drainage, development of ground-water supplies in the local shallow aquifer system, and urbanization. A general discussion of these activities, and their potential impact, follows.

\section{DRAINAGE}

The wetland would be adversely affected by drying. Drainage ditches could lower the water table, remove the stable ground-water supply, and dry the organic soils. Vegetation will change in response to the drier conditions. Dried organic soils decompose (oxidize) rapidly.

The north part of the wetland has been ditched. Ground-water inflow (and streamflow) in the upper channel reaches appears less, and stream temperatures appear less stable, than in other parts of the wetland. Soils there are drier and weed communities are established. Some of the land north of the wetland probably was made suitable for agriculture as a result of drainage.

Deep ditches that cut through the organic soils into the underiying sand lower ground-water levels in the sand aquifer and dry the overlying soils over extensive areas. Shallow ditches that do not cut through the organic soils do not lower ground-water levels in the underlying aquifer and dry the soils for only a short distance from the ditch itself. 


\section{GROUND-WATER PUMPAGE}

If water-supply development does not significantly reduce ground-water inflow, there will be no noticeable effect on the wetland. The 420.3 in of outflow plus the 30.6 in of underflow represent water not used in the study area. The 200-acre wetland adjoining the study area on the east uses 58 in of water for evapotranspiration. Theoretically, the remaining 392.9 in $(2,400 \mathrm{gal} / \mathrm{min})$ of water is surplus.

The wetland will show signs of stress if too much water is diverted to other uses. As ground-water withdrawal increases, springflow, underflow and leakage upward into the organic soils will decrease. Springflow, the only component that can be measured directly, could be monitored to indicate the effect of water-supply development upon the hydrologic system supporting the wetland.

Development of the deeper aquifer has had minimal effect on the upper aquifer supplying water to the Nevin wetland. Nearby wells in Madison and Fitchburg have been pumped since the late 1960's, but drawdown in the upper aquifer by 1970 was only a foot or two (McLeod, 1975, fig. 8). The deep aquifer apparently is separated from the upper aquifer by leaky confining layers (McLeod, 1975, p. 11-13). Because these layers allow downward leakage, development of the deep aquifer may capture some water from the shallow system, but at current development levels there has been little effect on the upper aquifer and on the Nevin wetland.

\section{URBANIZATION}

Urban development in the basin can affect the wetland in many ways. Poor construction practices can increase sediment yields during snowmelt and storms. Additional paved or roofed areas will increase surface-water inflow and may increase the amount of suspended and dissolved material transported. Other activities can increase surface-water inflow, or the materials carried by it. However, because surface-water flow is such a small part of the water budget, diverting it away from the wetland would have little effect.

\section{SUMMARY}

The Nevin wetland is a ground-water discharge area. During the study period, 1974 through 1976, ground-water inflow from springs, artesian wells, and upward leakage through the organic soil provided 89 percent of the water entering the wetland. Precipitation accounted for 7 percent, and surface-water inflow provided the remaining 4 percent. Only 8 percent of the inflow evaporated or was used by plants; the rest discharged as streamflow.

The wetland reduced the amount of suspended and dissolved material in water moving through it. About 80 percent of the sediment that entered was deposited near the wetland's edges and along stream channels. Twenty percent less nitrogen left the wetland than entered it; 7 percent less 
phosphorus left than entered. Ground-water inflow was the primary source of nitrogen ( 95 percent). Ground-water inflow also was the primary source of phosphorus ( 66 percent); surface-water inflow supplied 31 percent, and precipitation supplied the rest ( 3 percent).

Past and present activities have influenced the current status of the wetland. Ditch construction and channel straightening have altered ground-water flow in some areas. Gravel pits and other structural changes have changed runoff characteristics. Agricultural fertilizer and road salt have influenced stream-water quality. Other aspects of land use and development in the basin also may have influenced the wetland.

Future developments in the basin could have greater impact than they have in the past. This report provides a basis for evaluating the potential impact of proposed developments. The water budget can be used to evaluate the impact of activities that may change source and amount of water entering the wetland. The sediment and nutrient budgets can be used to estimate the impact of activities that may change the source and amount of suspended or dissolved material contained in the water. 


\section{SELECTED REFERENCES}

Bay, R. R., 1966, Evaluation of an evapotranspirometer for peat bogs: Water Resources Research, Jan.-Feb., p. 437-442 \{1968\}.

Bedford, B. L., Zimmerman, E. H., and Zimmerman, J. H., 1974, Wetlands of Dane County, Wisconsin: Dane County Regional Plan. Comm., $331 \mathrm{p}$.

Cline, D. R., 1965, Geology and ground-water resources of Dane County, Wisconsin: U.S. Geol. Survey Water-Supply Paper 1779-U, 64 p., 8 plates.

Cowardin, L. M., Carter, Virginia, Golet, F. C., and LaRoe, E. T., 1976, Interim classification of wetlands and aquatic habitats of the United States: U.S. Fish and Wildlife Service, Adm. rept., 109 p.

Kluesner, J. W., 1972, Nutrient transport and transformations in Lake Wingra, Wisconsin: Madison, Wisconsin Univ., Ph.D. thesis.

Linde, A. F., 1973, Nevin study area: Wisconsin Dept. Nat. Resources map.

McLeod, R. S., 1975, A digital-computer model for estimating hydrologic changes in the aquifer system in Dane County, Wisconsin: Wisconsin Geol. and Nat. History Survey Inf. Circ. 30,40 p.

National Oceanic and Atmospheric Administration (NOAA), 1973-76, Climatological data (Wisconsin): Asheville, N.C.

Novitzki, R. P., 1973, Improvement of trout streams in Wisconsin by augmenting low flows with ground water: U.S. Geol. Survey Water-Supply Paper $2017,52 \mathrm{p}$.

Olcott, P. G., 1973, Bedrock topography of Dane County, Wisconsin: Wisconsin Geol. and Nat. History Survey unpublished map.

Shaw, S. P., and Fredine, C. G., 1956, Wetlands of the United States: U.S. Fish and Wildlife Service Circ. 39, 67 p.

Sturges, D. L., 1968, Evapotranspiration at a Wyoming bog: Jour. Soil and Water Conserv., p. 23-25.

Thornthwaite, C.W., and Mather, J. R., 1957, Instructions and tables for computing potential evapotranspiration and the water balance: Drexel Inst. Technology, Pubs. Climatology, v. 10, no. 3, p. 185-311.

Yanggen, D. A., Johnson, C. D., Lee, G. B., Massie, L. R., Mulcahy, I. F., Ruff, R. L., and Schoenemann, J. A., 1977, Wisconsin wetlands: Wisconsin Univ.-Extension, Pub. G2818, 28 p. 
(다 